\title{
From Teachers' Personal Achievement Goals to Students' Perceptions of Classroom Goal Structures: Via Student-oriented Goals and Specific Instructional Practices
}

\author{
Martin Daumiller \\ University of Augsburg
}

Oliver Dickhäuser

University of Mannheim

\author{
Michaela S. Fasching \\ University of Augsburg
}

\author{
Gabriele Steuer \\ University of Augsburg
}

\author{
Markus Dresel \\ University of Augsburg
}

\begin{abstract}
To enlighten how teachers' goals matter for instructional practices and classroom goal structures, we conducted a study with 84 secondary school teachers and their 1,447 students. Students reported classroom goal structures and specific mastery and performance-oriented instructional practices. Teachers reported personal achievement goals and student-oriented goals. Two-level modeling indicated that mastery-oriented instructional practices were predicted by teachers' student-oriented goals and, indirectly, by their personal mastery goals (positively) and performance approach goals (negatively), while performance-oriented instructional practices were negatively predicted by teachers' personal mastery goals. Classroom goal structures were closely related to these instructional practices and indirectly predicted by teachers' goals.
\end{abstract}

Keywords: teacher motivation, achievement goals, student-oriented goals, instructional practices, classroom goal structures

THIS PAPER IS UNDER REVIEW.

Please do not cite or distribute any portion without authors' permission.

The achievement goal approach is a powerful framework for explaining and predicting learning and achievement (for overviews, see Elliot \& Hulleman, 2017; Kaplan \& Maehr, 2007; Urdan \& Kaplan, 2020). After extensive research on students, this approach has also been applied to the population of teachers (Butler, 2007, 2014). Considerable evidence supports the assumption that teachers' goals influence their attitudes, professional learning behaviors, and professional stress experiences (see Butler, 2014). Beyond these effects on rather personal aspects, it was proposed that teachers' achievement goals also influence their instructional practices (Butler, 2007; Butler \& Shibaz, 2008). Previous studies have generally supported this assumption

Martin Daumiller, Michaela S. Fasching, Gabriele Steuer, Markus Dresel, Department of Psychology, University of Augsburg, Germany. Oliver Dickhäuser, Department of Psychology, University of Mannheim, Germany.

The study presented in this paper was funded by a grant from the German Federal Ministry of Education and Research to Markus Dresel (01 HJ 0902) and Oliver Dickhäuser (01 HJ 0901).

Please address correspondence to Markus Dresel, Department of Psychology, University of Augsburg, Universitätsstr. 10, 86135 Augsburg, Germany, Tel.: +49 821 598-2606, E-Mail: markus.dresel@phil.uni-augsburg.de. (e.g., Butler, 2012; Butler \& Shibaz, 2008; Daumiller et al., 2016; Han et al., 2015; Nitsche et al., 2013a; Retelsdorf et al., 2010; Retelsdorf \& Günther, 2011; Schiefele \& Schaffner, 2015; Shim et al., 2013), although several theoretical and empirical weaknesses still exist. In particular, the mechanisms and processes behind the postulated associations between teachers' achievement goals (which are, by definition, personal and self-directed) and their instructional practices (which should be first and foremost directed at their students) remain unclear. Additionally, an excessive use of teacher self-reports to assess instructional practices may lead to a common method bias when investigating associations with teachers' goals. The present study addresses these points by (a) distinguishing between two types of teachers' goals, namely personal achievement goals and student-oriented goals, and (b) focusing on their effects on specific instructional behaviors and classroom goal structures (Bardach et al., 2020; Meece et al., 2006) — as assessed by students. We propose a model to describe and explain these effects (teachers' personal achievement goals affecting students' perceptions of goal structures via student-oriented goals and specific instructional practices; Figure 1 ), and present results from a study with secondary 


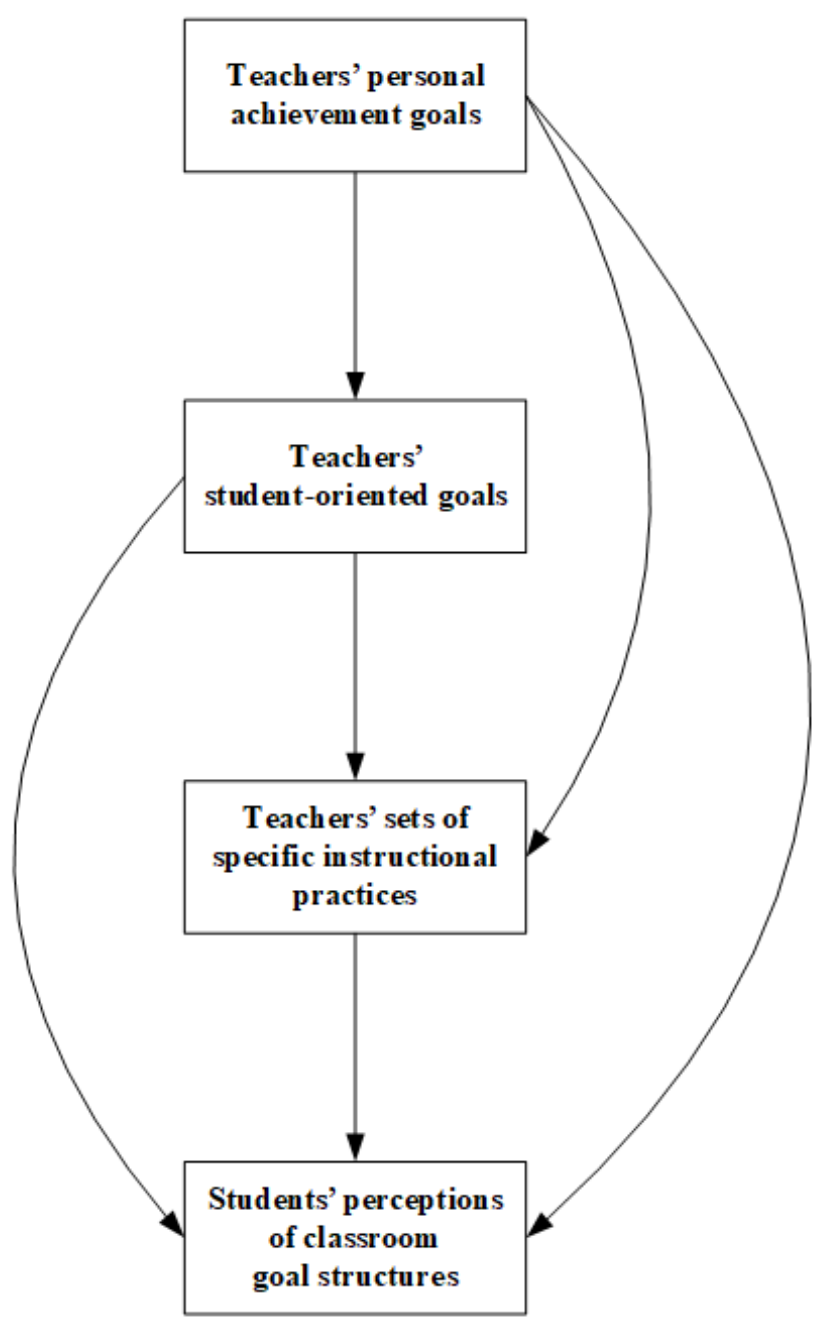

Figure 1: Proposed theoretical model of the effects of teachers' achievement goals on perceived classroom goal structures

school mathematics teachers and their students to test the proposed relationships.

\section{Achievement Goals of Teachers}

Butler (2007) described schools as achievement arenas, not only for students, but also for teachers, in which they may pursue different goals for themselves. According to Butler (2007; see also Papaioannou \& Christodoulidis, 2007), the following types of achievement goals can be distinguished in teachers: mastery goals (the aim to develop own competence), performance approach goals (the aim to demonstrate own competence), and performance avoidance goals (the aim to hide own assumed absent competence). ${ }^{1}$ As research has shown, these different goals meaningfully explain differences in teachers' cognitions and behaviors: Findings indicate positive relations between teachers' mastery goals and adaptive attitudes about help, positive help seeking, self-efficacy, job satisfaction, and professional development; in contrast, teachers' performance avoidance goals have been found to be positively associated with maladaptive attitudes, reduced self-efficacy, professional stress experiences, and number of sick days (e.g., Cho \& Shim, 2013; Daniels et al., 2013; Gorozidis \& Papaioannou, 2014; Janke et al., 2019; Nitsche et al., 2011, 2013a,b; Runhaar et al., 2010; Skaalvik \& Skaalvik, 2017). For performance approach goals, these studies found ambivalent or no substantial effects on teachers' cognitions and behaviors (similarly to students, e.g., Midgley et al., 2001).

\section{Teachers' Achievement Goals and their Instruc- tional Practices}

Researchers have also assumed that teachers' achievement goals may influence their instructional practices and, in turn, student learning (Butler, 2007; Butler \& Shibaz, 2008). Some studies have already provided evidence that supports this assumption-Table 1 presents an overview of these studies and their findings, which we describe next. 
Table 1

Overview of Studies that Investigated Associations between Teacher Goals and Instructional Practices

\begin{tabular}{|c|c|c|c|c|c|c|}
\hline \multirow[b]{2}{*}{ Study } & \multirow[b]{2}{*}{ Sample } & \multicolumn{2}{|c|}{ Instructional practices } & \multicolumn{3}{|c|}{ Goal effects } \\
\hline & & Assessed by & Aspect & MA & PA & PV \\
\hline \multicolumn{7}{|c|}{ I. Studies with instructional practices assessed exclusively by teacher self-reports } \\
\hline \multirow{4}{*}{$\begin{array}{l}\text { Butler (2012), } \\
\text { Study } 1\end{array}$} & \multirow{4}{*}{$\begin{array}{l}272 \text { Israeli elementary and secondary } \\
\text { school teachers }\end{array}$} & \multirow[t]{4}{*}{ Teachers } & Social support & & & \\
\hline & & & Mastery-oriented practices & + & & \\
\hline & & & Performance-oriented practices & & + & + \\
\hline & & & Low demands & & + & + \\
\hline \multirow{2}{*}{$\begin{array}{l}\text { Butler \& Shibaz } \\
\text { (2014), Study } 1\end{array}$} & \multirow[t]{2}{*}{341 Israeli teachers } & \multirow[t]{2}{*}{ Teachers } & Social support & & & \\
\hline & & & Cognitive stimulation & + & & \\
\hline \multirow[t]{2}{*}{ Daniels (2015) } & \multirow[t]{2}{*}{43 Canadian teachers } & \multirow[t]{2}{*}{ Teachers } & Mastery-oriented practices & + & & \\
\hline & & & Performance-oriented practices & & & \\
\hline Daumiller et al. (2019) & 1,066 German higher education teachers & Teachers & Overall teaching quality & + & + & + \\
\hline \multirow{4}{*}{$\begin{array}{l}\text { George \& Richardson } \\
\text { (2019) }\end{array}$} & \multirow{4}{*}{$\begin{array}{l}257 \text { Australian primary and secondary } \\
\text { school teachers }\end{array}$} & \multirow[t]{4}{*}{ Teachers } & Expectation & + & (na) & (na) \\
\hline & & & Structure & + & (na) & (na) \\
\hline & & & Autonomy support & + & (na) & (na) \\
\hline & & & Relatedness & + & (na) & (na) \\
\hline \multirow[t]{4}{*}{ Han et al. (2015) } & \multirow[t]{4}{*}{262 Chinese higher education teachers } & \multirow[t]{4}{*}{ Teachers } & Information transmission/teacher focused intention & + & + & + \\
\hline & & & Information transmission/teacher focused strategies & & + & + \\
\hline & & & Conceptual change/student-focused intention & + & + & + \\
\hline & & & Conceptual change/student-focused strategies & + & & + \\
\hline \multirow[t]{2}{*}{ Mascret et al. (2017) } & \multirow[t]{2}{*}{304 French high school teachers } & \multirow[t]{2}{*}{ Teachers } & Mastery-oriented practices & & & \\
\hline & & & Performance-oriented practices & & + & + \\
\hline \multirow{3}{*}{$\begin{array}{l}\text { Retelsdorf et al. (2010), } \\
\text { Study } 1\end{array}$} & \multirow{3}{*}{$\begin{array}{l}281 \text { German elementary and secondary } \\
\text { school teachers }\end{array}$} & \multirow[t]{3}{*}{ Teachers } & Mastery-oriented practices & + & & \\
\hline & & & Performance-oriented practices & & + & \\
\hline & & & Cognitive stimulation & + & & \\
\hline \multirow{3}{*}{$\begin{array}{l}\text { Retelsdorf et al. (2010), } \\
\text { Study } 2\end{array}$} & 69 Israeli secondary school teachers & Teachers & Mastery-oriented practices & + & & \\
\hline & & & Performance-oriented practices & & & + \\
\hline & & & Cognitive stimulation & + & & \\
\hline Retelsdorf \& & 206 German elementary and secondary & Teachers & Promotion of surface learning & & + & \\
\hline Günther (2011) & school teachers & & Promotion of comprehensive learning & & & \\
\hline Yin et al. (2017) & 595 Chinese higher education teachers & Teachers & Teacher-focused strategy & & + & + \\
\hline & & & Student-focused strategy & + & + & + \\
\hline & & Instructional & ractices & Goal e & ects & \\
\hline Study & Sample & Assessed by & Aspect & MA & $\mathrm{PA}$ & PV \\
\hline Shim et al. (2013) & 209 U.S. elementary and secondary & Teachers & Mastery-oriented practices & + & & \\
\hline & school teachers & & Performance-oriented practices & & + & \\
\hline Wang et al. (2017) & 495 Canadian elementary and secondary & Teachers & Mastery-oriented practices & + & & \\
\hline & school teachers & & Performance-oriented practices & & + & + \\
\hline
\end{tabular}

Butler (2012)

Study 2 school teachers 1,790 students

\section{Studies with instructional practices assessed by student perceptions}

73 Israeli secondary school teachers with Students Social support

Mastery-oriented practices

Performance-oriented practices

Low demands

Butler \& Shibaz (2008) 53 Israeli secondary school teachers with 1,287 students

Butler \& Shibaz 51 Israeli teachers with 1,280 students

Students

Teacher support

Teacher inhibition

(2014), Study 2

Daumiller et al.

(2016) 251 German higher education teachers

Students

Social support with 9,241 student assessments

Daumiller et al. (2021)

Study 1

Daumiller et al.

(2021a), Study 2

166 German higher education teachers with 2,106 student assessments 96 German higher education teachers with 16,009 student assessments

Dresel et al. (2013) 46 German secondary school teachers with 930 students

Cognitive stimulation

Students Overall teaching quality

Students Overall teaching quality

Students Overall teaching quality

Students

CGS mastery

CGS performance approach

CGS performance avoidance

Kalyar et al. (2018)

89 Pakistani elementary school teachers

Students

Mastery-oriented practices with 434 students.

Schiefele \& 110 German elementary school teachers Students ${ }^{2}$ Mastery-oriented practices Cognitive stimulation with 1,731 students

ces

Schaffner (2015)

(St) denotes a negative association. (na) denotes that the associations in question were not assessed/analyzed. MA $=$ mastery goals. PA $=$ performance approach go $\mathrm{PV}=$ performance avoidance goals. CGS = Classroom goal structure.

${ }^{2}$ Instructional practices were additionally assessed by teacher self-reports in this study.

The majority of these investigations focused on teachers' self-reports regarding instructional practices and processes. For example, Shim et al. (2013) asked
209 in-service teachers in the U.S. about their achievement goals for teaching and their classroom instruction in terms of the mastery vs. performance goal structures 
they set up (using the Patterns of Adaptive Learning Scales, PALS; Midgley et al., 2000). Results indicated that mastery goals went along with self-reported mastery-oriented teaching practices; and performance approach goals with performance-oriented instruction. Similar bivariate associations for mastery goals (but not for performance goals) were also reported in a sample of 43 Canadian teachers (Daniels, 2015). Finally, Mascret et al. (2017) found performance approach and avoidance goals to go along with increased self-reported performance-oriented practices of 304 French high school teachers.

Wang and colleagues (2017) also focused on the effects of achievement goals and self-reported masteryoriented and performance-oriented classroom practices investigating 495 Canadian teachers using a longitudinal design. Their findings affirmed that achievement goals were relevant for teachers' self-reported classroom goal structures six months later. However, the authors only found significant results for social and work avoidance goals, but no clear results for mastery and performance goals.

Another set of studies with 281, 69, and 206 teachers from Germany and Israel focused on self-reports of specific aspects of instructional practices. Retelsdorf et al. (2010) and Retelsdorf and Günther (2011) provided evidence that teachers' mastery goals are associated with instructional behaviors such as recognizing effort and progress that promote mastery goals, while performance goals were associated with using normative grading standards and competition that promote performance goals in the classroom. A study including 262 teachers in China, reported by Han et al. (2015), yielded comparable results, indicating positive associations between mastery goals and a self-reported student-focused approach to teaching, and between performance (approach and avoidance) goals and teacher-focused approaches.

\section{What do we Know Beyond Teachers'Self-reported In- structional Practices?}

While the above-described research studies consistently pointed to associations between mastery and performance goals and different instructional behaviors, a major limitation of these works is their reliance on selfreported data which can easily be biased by self-serving strategies or teaching ideals (Kunter \& Baumert, 2006). To date, only few studies have assessed instructional behavior in other ways, especially using student data. In comparison to the teacher self-report studies, these studies revealed rather mixed findings and weak associations between teachers' achievement goals and their instructional practices as perceived by students. Nevertheless, they also document the general relevance of the achievement goals that teachers set for themselves for the ways they teach in their classrooms.

On the level of more global instructional approaches, Dresel et al. (2013) found in a sample of 53 German teachers that perceived performance goal structures in the classroom were positively predicted by teachers' performance avoidance goals and negatively predicted by their mastery goals. Further, perceived mastery goal structures were positively predicted by teachers' performance approach goals. Dresel et al. (2013) also found effects from teachers' goals on students' motivation, mediated by their perceptions of the classroom goal structure.

As an aspect global instructional quality, students' assessments of overall teaching quality were considered in three studies by Daumiller et al. $(2016,2021)$ with 251, 166, and 96 German higher education teachers. Results revealed rather inconsistent findings, with one study documenting positive associations for mastery goals and negative associations for performance avoidance goals, another finding no statistically significant associations, and the third indicating positive associations for performance approach and avoidance goals.

Finally, another study with 110 German teachers, conducted by Schiefele and Schaffner (2015) indicated that teachers' mastery goals are positively associated with student reports of mastery-oriented instructional practices (and students' subject interest). These linkages between mastery-oriented practices and teachers' mastery goals were also found in a study by Kalyar et al. (2018) based on 89 Pakistani elementary school teachers.

On the level of more specific instructional practices, Butler and Shibaz (2008) investigated relations between achievement goals of 53 Israeli teachers and their students' perceptions of specific instructional behaviors regarding student help-seeking. They found that teachers' mastery goals were positively associated with perceived teacher support for question asking and help seeking. On the other hand, teachers' performance avoidance goals were positively correlated with perceived inhibition of students' question asking and help seeking.

In another study with 73 Israeli teachers, Butler (2012) provided support that teachers' achievement goals were linked to student reports of teachers' approaches to instruction. Mastery goals were negatively related to students' reported use of performance-based 
practices. However, mastery goals were not significantly associated with mastery-based practices, but relational goals were. It is worth noting that apart from a general perception of instructional behavior as expressed in the PALS framework, it proved successful in this study to include specific instructional behaviors, such as the provision of support to the students or teacher involvement. Ultimately, the authors foundopposed to the broad performance and mastery-based practices - clearer and theoretically consistent results for the specific outcomes.

How can we Learn More About the Relevance of Teachers' Goals for Students?

Taken together, these studies provide empirical support for the assumption that teachers' achievement goals influence actual teaching behavior. While the effects of mastery goals on mastery practices, and of performance avoidance goals on performance practices were found in many of these studies, there were also effects of mastery goals on performance practices, as well as of performance (approach and avoidance) goals on mastery practices (see Table 1). Interpreting the findings, it needs to be considered that teachers' instructional practices were mostly either measured by students' perceptions of classroom goal structures in general or by assessing only a few specific aspects of teachers' instructional practices. Both of these aspects might be a reason for non-correspondent and unexpected results. Besides this, previous investigations are limited as they focused on the direct effect from achievement goals on instructional practices.

In order to allow for a thorough understanding of teachers' achievement goals and their effects on instruction and to adequately examine their effects, we consider it necessary to investigate the underlying modes of action in detail. As teachers' personal achievement goals don't directly influence students' perceptions of classroom goal structures, but rather through differences in cognition (such as goals held for their students) and behaviors (such as instructional practices), only investigating correspondences between these two aspects may be too short sighted. Instead, the underlying mediation process need to be elaborated on. To this end, previous research indicated that it is sensible to include teachers' specific instructional practices as an intermediate variable - however, taking up the research deficits of previous works, this variable should be assessed using detailed student assessments of a comprehensive range of instructional behaviors.

Another preceding mediator that possibly transmits teachers' personal achievement goals into their actual mastery or performance practices may be the goals that teachers hold for their students (see Daniels et al., 2013, for a similar argument). Thus, in the present work, we include not only teachers' personal achievement goals, but also their student-oriented goals and a broad range of specific instructional behaviors (assessed by students) as meditators, to explain the effects of teacher goals on student perceptions of classroom goal structures.

Teachers' Student-oriented Goals as Mediators Between Personal Achievement Goals and Instructional Practices

Apart from goals that are focused on teachers' own competence, we consider student-oriented goalsgoals that teachers hold for their students-as an important additional type of teacher goal. Presumably, they are located between teachers' personal achievement goals and their instructional practices (see Figure 1). The relevance of such goals has been highlighted in the initial work on teachers' achievement goals by Butler (2007), who emphasized that "teachers' goals are to a significant extent defined in terms of the achievement and well-being of others and namely their students" (p. 251). Daniels et al. (2013) provided a similar argument by investigating intended classroom goal structures as a consequence of teachers' personal achievement goals. The intended classroom goal structures that they examined were derived from the concept of classroom goal structures (measured with the PALS in a slightly adjusted version, Midgley et al., 2000) and associated with teachers' personal goals. Specifically, teachers' mastery goals were strongly positively associated with their intended mastery classroom goals, and moderately negatively with their intended performance classroom goals (Daniels et al., 2013). We take this work by Daniels et al. (2013) a step further by proposing student-oriented goals as the goals that teachers hold for their students. As such, this concept does not describe the teaching behaviors that one is aiming for, but very fundamentally, he outcomes that a teacher strives for their students to achieve (e.g., them mastering the course material, them scoring well in examinations). In consequence, this concept is conceptually analogous to teachers' personal achievement goals (that are directed at their own person) but the subjects that the goals are directed at differ. Because of this symmetry between personal (self-directed) goals and student-oriented goals, it stands to reason that teachers who hold mastery/performance goals for themselves, may also pursue mastery/performance goals for their students.

These associations between personal and studentoriented achievement goals can be explained by two 
theoretical perspectives: First, as personal achievement goals are based on which kinds of successes or competences teachers consider to be most valuable for themselves, it can be expected that these definitions of competence will be relevant for their student-oriented goals and instructional practices as well. Second, teachers' student-oriented goals and instructional practices might be based directly on their personal achievement goals, as they are relevant for the attainment of these goals. For example, to attain personal performance approach goals, it can be considered very helpful to also set strong performance goals for one's students and conduct performance practices, as this could enable better performance by one's students and as such, a more positive evaluation of the teachers themselves (by comparing their class results with the results of other classes/teachers).

Such a consideration of student-oriented goals as a theoretically separate type of goals next to teachers' personal achievement goals seems to be an important avenue for future research. Indeed, in early works on teacher goals, Butler (2007) concluded that there is a need for a framework that integrates teacher's personal and student-oriented goals; however, until now, this does not appear to have been explored yet. Therefore, we propose a framework that integrates and clearly separates teachers' personal goals, their student-oriented goals, and their instructional practices (Figure 1) and empirically test the proposed direct and indirect effects. In particular, we expect teachers' student-oriented goals to mediate the relation between their personal achievement goals and instructional practices. Knowledge on these processes is especially important for the understanding of teacher motivation and how it matters. In particular, by clearly distinguishing between teachers' personal goals, student-oriented goals, and instructional practices, the present work allows us to address why there can be a disconnect between what teachers believe, how students perceive their classroom practices, and how teachers' personal motivations influence student outcomes.

\section{Teachers' Instructional Practices and the TARGET Model}

The large bundle of teachers' specific instructional practices can be classified comprehensively by applying the TARGET model (Ames, 1992) that is wellgrounded in the achievement goal approach. Ames (1992) identified teacher behaviors that encourage students to adopt mastery or performance goals respectively, and classified these practices based on whether they reflect classroom mastery goal structures or classroom performance goal structures. In order to build a climate in class that enhances students' mastery goals and reduces their performance goals, a teacher should therefore use a range of mastery orientated instructional practices. According to the TARGET model, this concerns the dimensions of task (class activities, assignments, and tasks should be rich in variety and individual challenge and should create an active involvement), authority (students should participate in the instructional process by involving them in decision-making and providing opportunities to develop responsibility for their own learning), recognition (students' individual effort and improvement should be recognized and rewarded, while focusing on each child's self-worth), grouping (flexible and heterogeneous grouping arrangements should be used instead of homogenous grouping), evaluation (individual progress and improvement, instead of social comparisons, should be used as standards for performance, the monitoring of performance, and evaluative feedback), and time (students should be granted flexible time for their work, an individual pace of learning, and opportunities for improvement).

Lüftenegger and colleagues (2014) empirically investigated the assumptions of Ames (1992) and confirmed that a strong focus on these mastery-orientated instructional practices had a positive impact on students' personal mastery goals. These findings align with research documenting positive effects of individual aspects of the TARGET model on student motivation (e.g., Church et al., 2001; Turner et al., 2011). Importantly, however, Lüftenegger et al. (2014) demonstrated that the mastery practices of the TARGET model are best described, not on the level of the subdimensions, but rather as a single factor encompassing the individual aspects described above.

As pointed out above, previous works on the effects of teachers' goals are limited in that instructional practices were either measured by students' perceptions of classroom goal structures in general or by only assessing a limited range of specific practices. To avoid distorted results, using detailed student assessments of a comprehensive range of instructional behaviors as delineated in the TARGET model can be considered to be a promising avenue to move the field forward. Specifically, the systematic breath of individual practices included in the TARGET model avoids distortions that could occur when focusing only on general statements (that are difficult for student to assess, opposed to the specific instructional aspects included in the TARGET model) or on only a few specific practices (that might be differentially related to teacher goals). At the same time, their conceptualization on a general level (in the 
form of mastery vs performance practices) enables a clear theoretical alignment within achievement goal research and previous theorizing about the effects of teacher goals.

\section{Research Questions and Hypotheses}

In order to advance knowledge of the effects of teachers' achievement goals on students, the main objective of the present study was to enlighten the associations between teachers' personal achievement goals with their student-oriented goals, their specific instructional practices, and the goal structures in their classrooms. Student perceptions were used to assess teachers' instructional practices and classroom goal structures to overcome limitations associated with teacher self-reports.

To explain the effects of teachers' achievement goals on students' perceived classroom goal structures, we propose the theoretical model presented in Figure 1. We assume that these effects are - at least partly-mediated through teachers' student-oriented goals and their sets of specific instructional practices. Additionally, we assume that these effects are due to a number of different mechanisms.

Specifically, we expected that teachers' student-oriented goals and instructional practices can in part be explained by their achievement goals. Teachers may aim for their students to show better achievements than students from other classrooms (a student-oriented performance goal) in order to demonstrate their own competences as a teacher (a personal performance goal). Additionally, they may use mastery-oriented practices (such as using cognitively activating tasks) to gain new insights into applying these practices and, thus, expand their teaching competences (a personal mastery goal). Further, we assume that instructional practices are associated with their student-oriented goals - for example, mastery-oriented practices help to accomplish teachers' goals that students should learn something meaningful. Regarding students' inferences of classroom goal structures - conceptualized as perceptions of the goal-related messages in the classroom (Meece et al., 2006) - it can be assumed that they depend on students' perceptions of specific instructional practices of their teachers and their immanent focus on mastery or performance. When students, for instance, perceive that their teacher relies heavily on intrapersonal grading standards when providing feedback, they should more likely perceive a mastery goal structure. Finally, it should be acknowledged that teachers could explicitly communicate their student-oriented goals and model their personal achievement goals, which might directly influence students' perceptions of classroom goal structures.

With respect to the direction of the assumed effects, we expected positive associations between corresponding dimensions. For example, we assumed that teachers' personal preference for mastery goals is positively associated with their student-oriented mastery goals (see Daniels et al., 2013), which, in turn, are associated with student perceptions of specific mastery-oriented practices of their teachers and mastery goal structures in the classroom (see Butler \& Shibaz, 2008; Retelsdorf et al., 2010). Alongside this, we assumed associations between non-corresponding dimensions. Specifically, we expected negative associations between mastery and performance avoidance components (e.g., a negative effect of performance avoidance goals on mastery practices or, vice versa, a negative effect of mastery practices on perceptions of a performance avoidance goal structure; see Patrick et al., 2001). According to the ambivalent nature of performance approach goals (see Midgley et al., 2001), we had no directed hypotheses regarding the associations of mastery components with performance approach components (or general performance components that are not differentiated with regard to value).

\section{Procedure and Participants}

Method

We conducted a study in mathematics classrooms by linking teachers' achievement goals and student-oriented goals with students' reports of instructional practices and classroom goal structures. Specifically, we investigated teachers from general-education secondary schools (In Germany, these schools are categorized by the term "Hauptschule", which refers to the lowest track in secondary education) in the southern part of Germany together with the students in their mathematics classrooms. School principals were contacted by mail and given written information about the studyresulting in 37 participating schools $(14.5 \%$ of contacted schools). Within these schools, $7^{\text {th }}$ to $9^{\text {th }}$ grade class teachers were asked for participation with their main class if they also taught mathematics in it (teachers in the participating general-education secondary schools usually function as class teachers, meaning that they teach most of the subjects in one class instead of teaching one or two subjects in many classes). Participation was voluntary and anonymous for teachers and students. We received informed consent from all participating teachers and the parents of the participating students. A total of 90 teachers with 1,525 students agreed to participate $(29.2 \%$ of contacted teachers and of $81.9 \%$ of contacted students). The data from six 
Table 2

Descriptive Statistics

\begin{tabular}{|c|c|c|c|c|c|c|}
\hline & \multicolumn{2}{|c|}{ Range } & \multirow[b]{2}{*}{$M$} & \multirow[b]{2}{*}{$S D$} & \multirow[b]{2}{*}{$\omega$} & \multirow[b]{2}{*}{ ICC } \\
\hline & Potential & Actual & & & & \\
\hline \multicolumn{7}{|c|}{ Teacher reports } \\
\hline \multicolumn{7}{|l|}{ Teachers' personal achievement goals } \\
\hline Mastery & $1-5$ & $2.1-5.0$ & 4.23 & 0.52 & .92 & - \\
\hline Performance approach & $1-5$ & $1.0-5.0$ & 1.83 & 0.82 & .97 & - \\
\hline Performance avoidance & $1-5$ & $1.0-3.4$ & 1.91 & 0.75 & .96 & - \\
\hline Teachers' student-oriented goals & & & & & & - \\
\hline Mastery & $1-6$ & $3.8-5.8$ & 4.93 & 0.51 & .80 & - \\
\hline Performance & $1-6$ & $1.2-4.9$ & 3.42 & 0.76 & .90 & - \\
\hline \multicolumn{7}{|c|}{ Student reports } \\
\hline \multicolumn{7}{|l|}{$\begin{array}{l}\text { Teachers' instructional practices } \\
\text { Task }\end{array}$} \\
\hline Interestingness of instruction & $1-5$ & $1.0-5.0$ & 3.29 & 0.78 & .92 & $.18^{*}$ \\
\hline Cognitive stimulation & $1-5$ & $1.0-5.0$ & 3.25 & 0.55 & .73 & $.11^{*}$ \\
\hline Structuring of content & $1-5$ & $1.0-5.0$ & 2.94 & 0.81 & .78 & $.10^{*}$ \\
\hline Clarity of explanations & $1-5$ & $1.0-5.0$ & 3.76 & 0.91 & .86 & $.18^{*}$ \\
\hline \multicolumn{7}{|l|}{ Authority } \\
\hline Autonomy support & $1-5$ & $1.0-5.0$ & 3.69 & 0.69 & .80 & $.16^{*}$ \\
\hline \multicolumn{7}{|l|}{ Recognition } \\
\hline Support for competence & $1-6$ & $1.0-6.0$ & 4.40 & 0.83 & .87 & $.12^{*}$ \\
\hline Constructive error climate & $1-6$ & $1.6-5.9$ & 4.39 & 0.64 & .93 & $.18^{*}$ \\
\hline Support for relatedness & $1-6$ & $1.0-6.0$ & 4.10 & 1.06 & .88 & $.21^{*}$ \\
\hline \multicolumn{7}{|l|}{ Grouping } \\
\hline Homogeneous grouping & $1-5$ & $1.0-5.0$ & 2.02 & 1.01 & .89 & $.12^{*}$ \\
\hline Heterogeneous grouping & $1-5$ & $1.0-5.0$ & 3.42 & 0.90 & .77 & $.06^{*}$ \\
\hline Cooperation & $1-5$ & $1.0-5.0$ & 3.24 & 0.74 & .91 & $.15^{*}$ \\
\hline Competition & $1-5$ & $1.0-5.0$ & 2.40 & 0.81 & .91 & $.11^{*}$ \\
\hline \multicolumn{7}{|l|}{ Evaluation } \\
\hline Intrapersonal grading standards & $1-6$ & $1.0-6.0$ & 4.86 & 0.84 & .74 & $.04^{*}$ \\
\hline Normative grading standards & $1-6$ & $1.0-6.0$ & 3.10 & 1.32 & .87 & .02 \\
\hline Publication of marks & $1-6$ & $1.0-6.0$ & 2.58 & 1.33 & .84 & $.20^{*}$ \\
\hline Public negative feedback & $1-5$ & $1.0-5.0$ & 2.42 & 0.87 & .74 & $.08^{*}$ \\
\hline \multicolumn{7}{|l|}{ Time } \\
\hline Individualization of learning time & $1-5$ & $1.0-5.0$ & 2.82 & 0.76 & .71 & $.08^{*}$ \\
\hline \multicolumn{7}{|l|}{ Classroom goal structures } \\
\hline Mastery & $1-6$ & $1.0-6.0$ & 4.53 & 0.84 & .90 & $.07^{*}$ \\
\hline Performance approach & $1-6$ & $1.0-6.0$ & 4.17 & 1.02 & .93 & $.03 *$ \\
\hline Performance avoidance & $1-6$ & $1.0-6.0$ & 3.30 & 1.21 & .92 & $.03^{+}$ \\
\hline
\end{tabular}

Note. $N=84$ teachers and $N=1,447$ students. ICC $=$ Intraclass correlation, quantifies the proportion of between classroom variance on total variance. Zero order correlations are provided in an electronic supplement.

${ }^{*} p<.05,{ }^{+} p<.10$.

classrooms were excluded due to missing teacher questionnaires. This resulted in a final sample of 84 teachers $(59.5 \%$ female; mean age $=43.2$ years, $S D=10.8$; mean teaching experience $=17.2$ years, $S D=12.0$ ) and 1,447 students $(44.0 \%$ female; mean age $=14.4$ years,
$S D=1.06 ; 29.1 \%$ seventh, $41.5 \%$ eighth and $29.4 \%$ ninth graders; $36.9 \%$ with immigrant background).

The study was conducted in full accordance with the Ethical Guidelines of the German Association of Psy- 
chologists and the American Psychological Association and we had written approval from the Ministry of Education. We had no reason to assume that completing our surveys would have any negative effects on the participants. Data were collected by two trained research assistants during regular classroom instruction (students and teachers answered their questionnaires at the same time).

\section{Measurements}

All items were presented along with Likert-type scales. Table 2 presents the ranges and internal consistencies (McDonald's $\omega$ ).

\section{Teachers' Achievement Goals}

We measured teachers' achievement goals with the Nitsche et al. (2011) questionnaire. Mastery goals were assessed with 9 items (e.g., "In my vocation, I aspire to improve my pedagogical knowledge and my competences"). Performance approach goals and performance avoidance goals were each measured with 12 items (e.g., "In my vocation, I aspire my colleagues to realize that I teach better than other teachers", "In my vocation, I aspire my students not to believe I would master my job less sufficient than other teachers").

\section{Teachers'Student-oriented Goals}

In correspondence with Daniels et al.'s (2013) twodimensional conceptualization of teachers' intended classroom goals, we measured student-oriented mastery goals ( 8 items, e.g., "In my math class, it is my main goal that my students continue to learn and improve themselves") and student-oriented performance goals (12 items, e.g., "In my math class, my most important goal is that my students score well in examinations") $)^{2}$ with a newly developed questionnaire. The items were derived by systematically considering existing scales by Buck et al. (1992), Daniels et al. (2013), and Midgley et al. (2000) on related constructs. To content-validly represent the construct in question, we distinguished between different facets of the student-oriented goals (learning, improving, expanding competencies, and understanding as aspects of learning goals that were operationalized with two items each; getting good grades, and getting better grades than others as well as not getting bad grades, and not getting worse grades than others as aspects of performance approach and avoidance goals, assessed with three items each). Confirmatory Factor Analyses confirmed that a two-factor model distinguishing between student-oriented mastery and performance goals described the data better than a single factor and that it was superior to a three-factor model that distinguished between student-oriented performance approach and avoidance goals, while all factor loadings were in a satisfactory range $(\beta=.41-.82$ for mastery goals, $\beta=.52-.84$ for performance goals). All items are provided in an electronic supplement.

\section{Students' Perceptions of Teachers' Instructional Practices}

To assess instructional practices in a comprehensive manner, we measured the multifaceted dimensions of the TARGET model (Ames, 1992) with a total of 17 subscales that were mainly slight adaptations of scales used in large-scale studies. Using student ratings encompassing many different aspects offers a good opportunity to capture instructional practices in a comprehensive way (Kunter \& Baumert, 2006). The first TARGET dimension, "task", was measured with the following scales: interestingness of instruction (6 items, e.g., "Our teacher diversifies our Math class", Baumert et al.; 2008), cognitive stimulation (6 items, e.g., "In our Math class, our teacher asks questions that you can't answer spontaneously, but that encourage you to think about them", Ramm et al.; 2006), structuring of content (4 items, e.g., "Our teacher presents Math content in a logical order"; Baumert et al., 2008), and clarity of explanations (3 items, e.g., "In Math, our teacher explains things well"; Baumert et al., 2008). The second dimension, "authority", was assessed using an autonomy support scale (6 items, e.g., "In our Math class we are encouraged to work autonomously"; Black \& Deci, 2000). "Recognition" was measured by assessing support for competence (7 items, e.g., "In our Math class I can contribute what I know"; Baumert et al., 2008), constructive error climate (31 items, e.g., "In our Math class wrong answers are often a good opportunity to really understand the material"; Steuer et al., 2013), and support for relatedness (5 items, e.g., "In our Math class I feel understood and supported by my teacher"; Wild, 1999). Regarding the "grouping" dimension, we assessed homogeneous grouping (3 items, e.g., "If we're working in groups or with partners in our Math class, high-achieving students work with high-achieving students and low-achieving students work with low-achieving students", newly developed) as well as heterogeneous grouping (3 items, e.g., "If we're working in groups or with partners in our Math class, students with different achievement levels work with each other in every group", newly developed), cooperation (6 items, e.g., "In our Math class the teacher shows us how we can help each other"; Baumert et al., 2008), and competition (6 items, e.g., "In our Math class we are encouraged to compete"; Ramm et al., 2006). The dimension "evaluation" was measured with the scales use of intrapersonal grading standards (3 items, e.g., "For my teacher, a good result in Math is if someone has improved"; Schöne et al., 2004), use of normative grading 
standards (3 items, e.g., "For my teacher, a good result in Math is if someone is better than others"; Schöne et al., 2004), publication of marks (3 items, e.g., "In our Math class everyone gets to know which student has which mark", newly developed), and public negative feedback (3 items, e.g., "In our Math class, the teacher criticizes students explicitly in front of the class"; Dresel et al., 2009). The final dimension, "time", was assessed with the scale individualization (5 items, e.g., "In our Math class, faster students can work on extra tasks"; Ramm et al., 2006).

\section{Students' Perceptions of Classroom Goal Struc- tures}

Classroom goal structures were assessed using three subscales from the PALS (Midgley et al., 2000). Perceived mastery classroom goal structure was measured with 6 items (e.g., "In our Math class, really understanding the material is the main goal"). Perceived performance approach classroom goal structure was assessed with 3 items (e.g., "In our Math class, getting good grades is the main goal"), and perceived performance avoidance classroom goal structure with 5 items (e.g., "In our Math class, showing others that you are not bad at class work is really important").

\section{Missing Values and Data Analysis}

Missing values due to item non-response occurred rarely (less than $8 \%$ for teachers and less than $11 \%$ for students). They were imputed using the expectationmaximization algorithm (Peugh \& Enders, 2004).

We adopted a two-level analysis strategy to represent the nested data structure-here, teachers' goals as well as students' shared perceptions are located at level 2 (between teachers/classrooms) and students' individual perceptions are located at level 1 (students within teachers/classrooms). Concerning the research questions at hand, level 2 is of core interest. To account for covariation between the multiple dimensions of instructional practices and to limit the number of variables in the main analyses, we performed two-level exploratory factor analyses in a preliminary step (Muthén \& Asparouhov, 2009). To test the assumptions derived from the proposed theoretical model, we applied twolevel path analyses and tested indirect effects. Modeling was performed using Mplus 8.1 using the accelerated expectation maximization algorithm (Muthén \& Muthén, 2018).

\section{Descriptive Statistics}

\section{Results}

Descriptive statistics can be found in Table 2. For nearly all facets of teachers' instructional practices, significant and considerable between-teacher variation (intraclass correlations ICC) was observed in students' perceptions. The only exception was the scale "normative grading standards", which was consequently excluded from further analyses. The proportions of between-teacher variance for perceived classroom goal structures were smaller but nevertheless significant (performance avoidance goal structure: $p=.08$ ).

\section{Super-ordinated Factors of Instructional Practices}

We conducted a two-level exploratory factor analysis of the different aspects of teachers' instructional practices. Eigenvalues suggested up to three principal components on the between-teacher-level $(7.61,2.81$, $1.34,0.96,0.80 \ldots)$ and up to two principal components on the within-teacher-level $(4.65,2.53,0.99,0.96,0.85$ ...). A factor solution (Geomin rotation) with two factors on the between-teacher-level and two factors on the within-teacher-level fit sufficiently $\left(\chi^{2}=617.7\right.$, $\mathrm{df}=178, \mathrm{RMSEA}=.04, \mathrm{CFI}=.94, \mathrm{TLI}=.92)$ and better to the data than solutions with fewer factors $\left(\chi^{2}=684.7-2327.4, \mathrm{df}=193-208, \mathrm{RMSEA}=.04-.08\right.$, $\mathrm{CFI}=.70-.93, \mathrm{TLI}=.65-.91)$. On the other hand, a solution with three factors on the between-teacher-level did not improve the model fit substantially $\left(\chi^{2}=586.4\right.$, $\mathrm{df}=164, \mathrm{RMSEA}=.04, \mathrm{CFI}=.94, \mathrm{TLI}=.91)$ and had no significant loadings on the third factor. Consequently, we decided for the model with two factors on the between-teacher-level and the within-teacher-level each.

The pattern of factor loadings on the betweenteacher-level was quite similar to that of the withinteacher-level (Table 3). Thus, factors can be interpreted as conceptually similar on both levels. The first factor can be labeled in accordance with conceptualizations in the literature (e.g., Midgley et al., 2000) as mastery practices - it had strong loadings of interestingness of instruction, cognitive stimulation, structuring of content, clarity of explanations, autonomy support, support for competence, constructive error climate, support for relatedness, use of heterogeneous grouping, cooperation, and use of intrapersonal grading standards. For the second factor, relatively strong positive loadings of the use of homogeneous grouping, competition, publication of marks and public negative feedback were observed - thus it can be labeled as performance practices. Interestingly, individualization of learning time also loaded on this factor, although it is described as a mastery practice in the literature (Ames, 1992). ${ }^{3}$ Factor correlations between mastery and performance practices were $r=-.09$ and $r=-.15$ on the within- and between-teacher-level, respectively. 
Table 3

Two-Level Exploratory Factor Analysis of Student Perceptions of Teachers' Instructional Practices

\begin{tabular}{|c|c|c|c|c|}
\hline \multirow[b]{2}{*}{$\begin{array}{l}\text { TARGET-Dimension sensu Ames (1992) } \\
\text { Specific instructional practices }\end{array}$} & \multicolumn{2}{|c|}{ Within-teacher-level loadings } & \multicolumn{2}{|c|}{ Between-teacher-level loadings } \\
\hline & $\begin{array}{l}\text { Mastery } \\
\text { practices }\end{array}$ & $\begin{array}{l}\text { Performance } \\
\text { practices }\end{array}$ & $\begin{array}{l}\text { Mastery } \\
\text { practices }\end{array}$ & $\begin{array}{l}\text { Performance } \\
\text { practices }\end{array}$ \\
\hline \multicolumn{5}{|l|}{ Task } \\
\hline Interestingness of instruction & $.79^{*}$ & .02 & $.94 *$ & .16 \\
\hline Cognitive stimulation & $.46^{*}$ & $.08^{*}$ & $.62^{*}$ & $-.32 *$ \\
\hline Structuring of content & $.52^{*}$ & $.11^{*}$ & $.79^{*}$ & -.22 \\
\hline Clarity of explanations & $.73^{\star}$ & $-.18^{*}$ & $.95^{*}$ & -.05 \\
\hline \multicolumn{5}{|l|}{ Authority } \\
\hline Autonomy support & $.60^{*}$ & .01 & $.92 *$ & .01 \\
\hline \multicolumn{5}{|l|}{ Recognition } \\
\hline Support for competence & $.68^{*}$ & $-.08 *$ & $.93^{*}$ & -.02 \\
\hline Constructive error climate & $.60^{*}$ & $-.44^{*}$ & $.89^{*}$ & .02 \\
\hline Support for relatedness & $.71^{*}$ & -.04 & $.89^{*}$ & $.30^{*}$ \\
\hline \multicolumn{5}{|l|}{ Grouping } \\
\hline Homogeneous grouping & -.04 & $.53^{*}$ & -.17 & $.82 *$ \\
\hline Heterogeneous grouping & $.28 *$ & .04 & $.57^{*}$ & -.04 \\
\hline Cooperation & $.65^{\star}$ & $.22 *$ & $.67^{*}$ & $.38^{*}$ \\
\hline Competition & $.26^{*}$ & $.67^{*}$ & .19 & $.61^{*}$ \\
\hline \multicolumn{5}{|l|}{ Evaluation } \\
\hline Intrapersonal grading standards & $.36^{*}$ & -.04 & $.57^{*}$ & $-.63^{*}$ \\
\hline Publication of marks & $-.08^{*}$ & $.47^{*}$ & .03 & .29 \\
\hline Public negative feedback & -.01 & $.60^{*}$ & -.26 & $.38^{*}$ \\
\hline \multicolumn{5}{|l|}{ Time } \\
\hline Individualization of learning time & $.28^{*}$ & $.59 *$ & .19 & $.61^{*}$ \\
\hline
\end{tabular}

Two-level Path Modeling the Relations Between Teachers' Achievement Goals and Students' Perceptions of Classroom Goal Structures

We performed two-level path analyses to model the expected associations between teachers' achievement goals and classroom goal structures, which we assumed to be mediated by teachers' student-oriented goals and their instructional practices (see Figure 1). First, we inserted students' perceptions of classroom goal structures and instructional practices (the two factors representing mastery and performance practices) on both the between- and within-teacher-level. Subsequently, we included teachers' student-oriented goals and personal achievement goals on the between-teacher-level. Paths that were not in the predicted direction or were not significant at the 5\%-level were fixed to nil successively (correlations within groups of variables were left in the model in any case). Additionally, we modeled indirect effects to test the assumed mediating role of teachers' student-oriented goals and instructional practices. The final model had an acceptable fit to data $\left(\chi^{2}=28.4\right.$, $\mathrm{df}=30, \mathrm{RMSEA}<.01, \mathrm{CFI}=1.00, \mathrm{TLI}=1.00)$ and is presented in Figure 2. ${ }^{4}$

The results indicated that teachers' personal mastery goals were moderately and positively associated with the extent to which they also pursue mastery goals for their students. On the other hand, their personal performance approach goals were strongly and positively related with their student-oriented performance goals. No significant effects were observed for teachers' personal performance avoidance goals.

Student perceptions of instructional mastery practices-such as cognitive stimulation, constructive error climate, or heterogeneous grouping-depended to a moderate degree on both teachers' student-oriented mastery goals (positive effect) and performance goals (negative effect). However, for performance practices - e.g., homogeneous grouping, competition, or public negative feedback - no statistically significant associations with teachers' student-oriented goals were observed. Instead, the degree to which teachers pursued personal mastery goals negatively predicted student perceptions of instructional performance practices moderately.

Finally, the bundle of specific mastery practices of their teachers was closely associated with perceptions of a strong global mastery goal structure (positive association) and a weak global performance avoidance goal structure (negative association). Further, specific performance practices were negatively related to perceptions of a global mastery classroom goal structure and positively to perceptions of a global performance 
Teachers' person al achievement go als

Teachers' student-directed goals

Teachers' instructional practices (shared percep tions of students)
Classroom goal structures (shared percep tions of students)

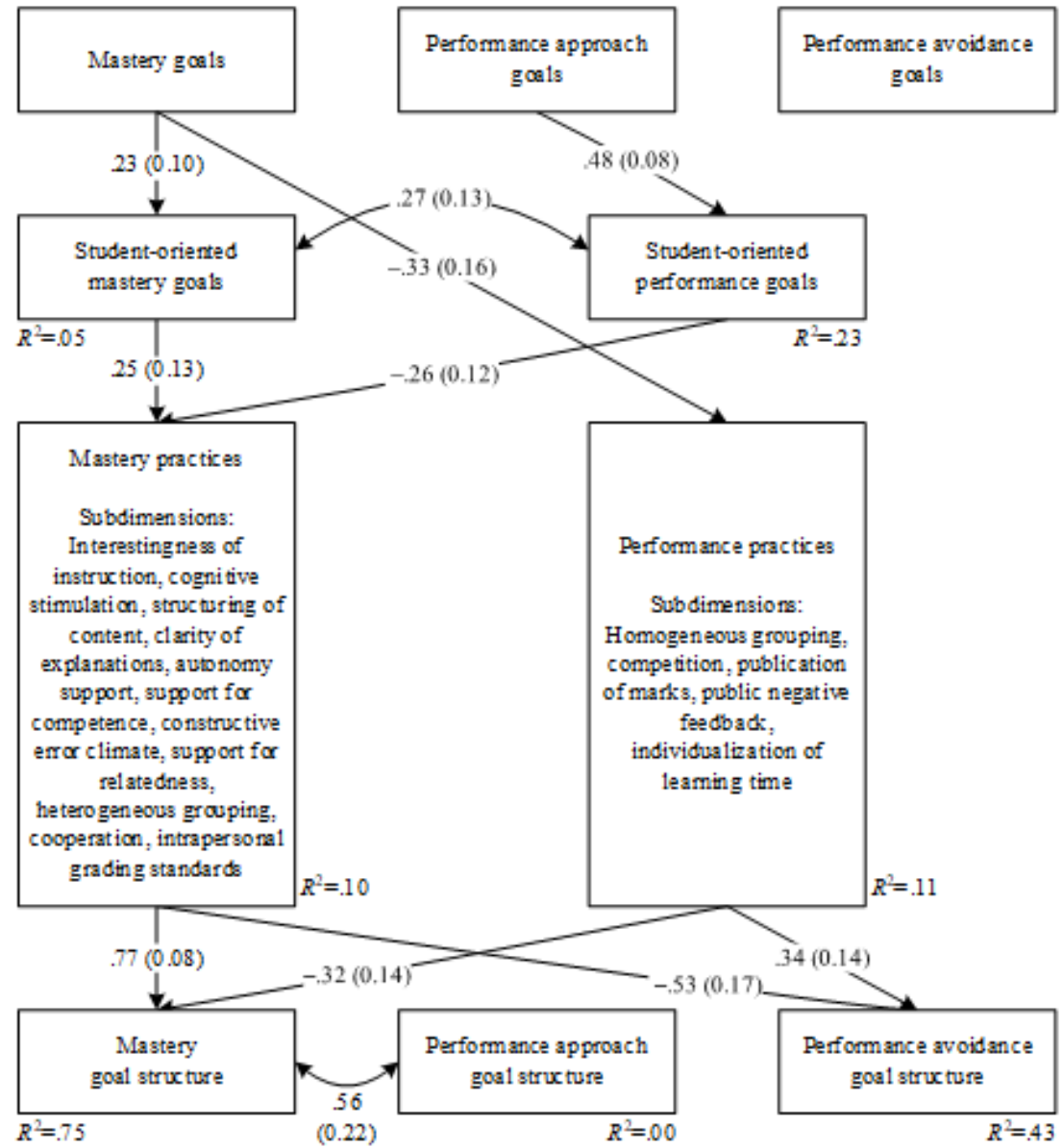

Between-te ac her-level (Classroom-level) Within-te ac her-level (Student-le vel)
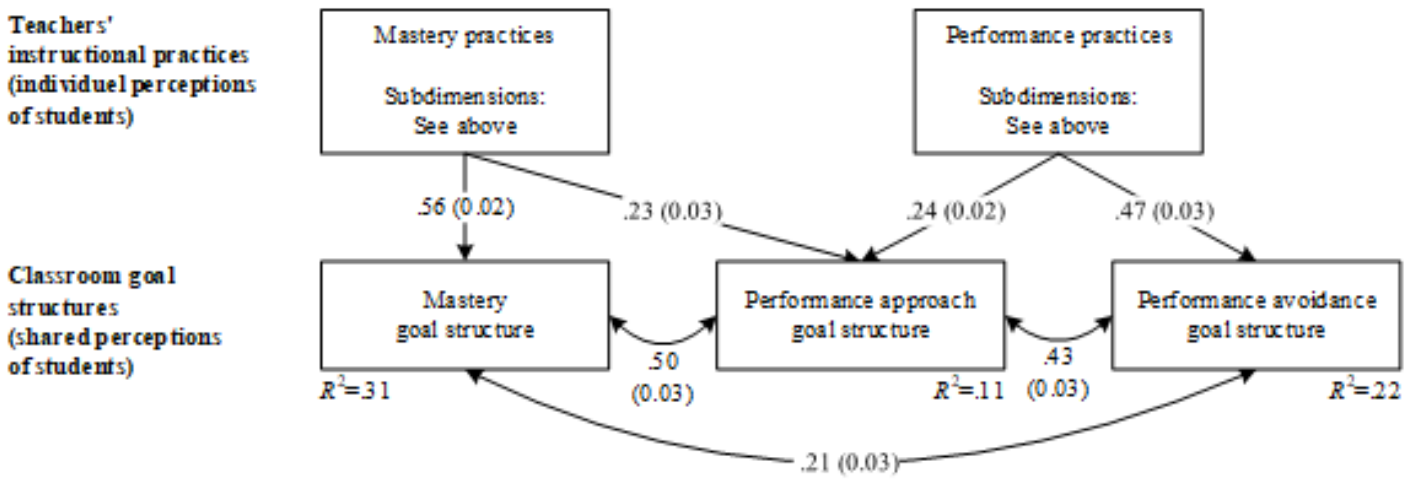

Figure 2: Two-level path model (all paths and correlations: $p<.05$ ).

avoidance classroom goal structure (both to a moderate degree). However, students' shared perceptions of a performance approach goal structure were not statistically significantly associated with instructional practices on the between-teacher-level. Paralleled results on the within-teacher-level-which is of minor relevance in the present context-were similar with regard to paths between corresponding components (e.g., mastery practices and mastery goal structures) and somewhat different with regard to paths between non-corresponding components (see Figure 2).

No direct effects of teacher goals on perceived classroom goals structures were evident. 
Concerning the mediational assumptions made in the proposed theoretical model, a series of indirect effects were found in the final two-level path model. First, we found an indirect effect of teachers' personal mastery goals on mastery classroom goal structure, mediated through teachers' student-oriented mastery goals and their mastery practices as well as through teachers' performance practices $(\beta=.15, \mathrm{SE}=.05, \mathrm{p}<.01)$. Second, a negative indirect effect of personal mastery goals of teachers on performance avoidance classroom goal structure with identical mediators was also found $(\beta=-$ $.14, \mathrm{SE}=.06, \mathrm{p}<.05)$. Third, there was an indirect effect of teachers' personal performance approach goals on mastery classroom goal structure, mediated through student-oriented performance goals and mastery practices $(\beta=-.10, \mathrm{SE}=.04, \mathrm{p}<.05)$. Finally, a positive indirect effect of personal performance approach goals on perceived performance avoidance classroom goal structure with identical mediators was observed $(\beta=.07, \mathrm{SE}=.03, \mathrm{p}<.05)$.

\section{Discussion}

In the present study we aimed to advance knowledge of the little investigated effects between teachers' achievement goals and perceived classroom goal structures by proposing and empirically testing a model that specifies and distinguishes student directed goals as mediators between teachers' personal goals, their instructional practices, and their effects on classroom goal structures. We resolved limitations of former studies by clearly disentangling and explicitly measuring student directed goals as a second type of teacher goal and by operationalizing teachers' specific instructional practices comprehensively according to the TARGET model (Ames, 1992) and measuring them, as well as classroom goal structures, by means of student perceptions. Strengths of the present work include its theory-derived approach, the innovative inclusion of goals that teachers hold for their students, the multilevel design, as well as the comprehensive and detailed assessment of instructional practices. Our findings confirmed our theoretical assumptions and advance knowledge of the effects of teachers' achievement goals on instruction.

\section{Student-oriented Goals}

To explain the effects of teachers' personal achievement goals on instructional behavior and goal structures in the classroom, we included student-oriented goals as a possibly important additional type of teacher goals. Despite having been proposed in early works on teacher goals (Butler, 2007), these goals have been widely neglected in previous research. Thus, we developed a scale specifically addressing student mastery and student performance as goal content. As far as we know, this was the first time that this type of goal was considered for full-service teachers.

Similar to the findings of Daniels et al. (2013) regarding intended classroom goal structures, our results indicated that achievement goals and student-oriented goals are partially associated, but also clearly distinct types of goals (as indicated by the not too strong associations between them) which were pursued to varying degrees by different teachers (as indicated by substantial variances, especially for student-oriented performance goals).

An important theoretical question concerns how personal achievement goals translate into student-oriented goals. Here, our findings indicated a difference between student-oriented mastery (5\% of which was explained by personal mastery goals) and performance goals (of which $23 \%$ was explained by personal performance goals). Indeed, setting student-oriented performance goals may be more helpful for teachers to demonstrate own competence (good student performance might more easily be attributable to good teacher acting) than setting student-oriented mastery goals for teachers to expand their own competence (providing good learning opportunities for students may not necessarily provide good learning opportunities for the teacher as well). On a more general level, this substantial, but only partial, overlap between both constructs provides insight into general motivational processes directed at oneself and others. Future research could profit from exploring this link in more detail, e.g., especially by following up on the weaker link between personal mastery and student-oriented mastery goals and including moderators such as implicit theories about the extent to which teachers believe that student learning opportunities also constitute good learning opportunities for themselves.

Student-oriented goals had explanatory power and thus appear to be an important aspect to include in future research on teacher motivation. In particular, our findings indicate strong merits of considering student directed goals when theorizing about (and empirically investigating) how teachers' goals matter for student outcomes-especially as teachers' personal achievement goals may not always go along with the expected student ratings (see Table 1 and Daumiller et al., 2021). When examining this additional type of goal, future research should also address the "why" behind these goals in detail in order to elucidate their link to personal achievement goals (also including underlying thirdvariables, such as ideals or value judgments). 


\section{Specific Instructional Practices}

Another novelty of the present work was its comprehensive assessment of instructional practices based on broad and detailed student ratings on the facets of the TARGET model (Ames, 1992). The betweenteacher differences that we found regarding student ratings of these instructional practices were in a similar range as those reported in comparable works (e.g., Butler, 2012; Butler \& Shibaz, 2008). The large number of specific instructional practices representing the six TARGET dimensions secures the appropriateness (i.e., broad content validity, generalizability, precision) of the instructional measure. It is important to note that this is the case despite their integration into super-ordinated factors that can be handled in the analyses (despite the present sample being quite large, it is not large enough to model all instructional dimensions separately). This approach is rooted in limitations of prior research that has frequently relied on teacher self-reports and focused only on selected aspects of instructional practices-making it difficult to generalize and adequately compare their results.

Taken together, our findings underpin the merits of using student ratings on specific instructional behaviors described in the TARGET model. Two-level exploratory factor analyses indicated a two-factorial solution showing that mainly a separation between mastery and performance-oriented practices seems to be adequate to group a large bundle of instructional behaviors. This is in line with findings by Lüftenegger et al. (2014) who demonstrated that mastery-based teaching behaviors conceptualized in the TARGET model are best described as a single factor on a higher level. Our results expand this research by indicating that next to mastery practices, it is also important to explicitly consider performance practices that imply a large visibility, demonstration, or comparison of student competence and competence deficits that may be particularly precarious for students (see Kaplan \& Maehr, 2007). The mapping of specific instructional behaviors to mastery or performance practices was as theoretically expected-with the exception of the individualization of learning time. Here, it might be the case that students perceive an individualized allocation of learning time as visible signs of performance and competence differences. Thus, even though individualization itself (in terms of adjusting task requirements on students' current competence levels) may be strongly supportive for mastery motivation, public communication about individualization may be detrimental. Another interpretation may be that students perceive individualization of learning time as an indicator of their teaching, believing that students have innate levels of ability (i.e., an environmental entity theory; see Rattan et al., 2012), which might enhance the perception of differences between students and, as such, contribute to a performance focus.

Mechanisms Behind the Effects of Teachers' Personal Achievement Goals on Classroom Goal Structures

Concerning the effects of teacher goals on perceived classroom goal structures, we postulated a theoretical model specifying a chain of mediators (Figure 1). In accordance with this model, the results revealed that student-oriented goals fully mediated the effects of teachers' personal goals on mastery-oriented instructional practices and classroom goal structures. This indicates that teacher goals that are directed at the development or demonstration of students' competence enhance or inhibit teacher behavior in the classroom that promote student mastery, respectively.

For performance-oriented instructional practices, this was not the case-instead, a direct negative effect from teachers' personal mastery goals on students' perceived performance practices was evident. This indicates that teachers inhibit performance practices when they strive to expand their own teaching competences, presumably because they ascribe these practices a relatively low potential to gain new insights into teaching (in that they have less freedom in the arrangement and innovation of such lessons). Thus, two structurally different mechanisms between teacher goals and their practices in the classroom may exist for mastery and performance aspects of instruction. It is worth noting that these results for performance goals are well in line with our systematic overview of prior studies that used student ratings to investigate the effects of teachers' goals on instruction (Table 1), which indicated that the effects for performance goals were especially unclear. Interpreting these findings of teachers' mastery goals appearing more relevant than performance goals for instructional practices and classroom goal structures, it should be borne in mind that the assessment of performance goals may be affected by socially desirable responding. Even though the study has been fully anonymous, teachers with strong performance goals may not fully admit to these goals if they are especially affected by this response bias (which might also account for the low mean levels of these types of goals that we observed). As such, it might be generally more difficult to detect effects for performance goals than for mastery goals - an issue that future research might try to address by including social-desirability scales as control variables. Furthermore, the partially weak effects which were observed despite the incorporation of two 
types of teacher goals indicate that moderators of the link between teachers' personal achievement goals and students' perceptions of instructional practices may additionally exist (e.g., Butler, 2012) — we consider their identification a worthwhile task for future research.

The present paper aimed to clarify the mechanisms and processes behind the associations between teachers' achievement goals and the goal structures they set up in class. With respect to this main research question, it is important to note that all effects of personal achievement goals of teachers on perceived classroom goal structures were fully mediated by their student-oriented goals and specific instructional practices (as indicated by a series of indirect effects). Unexpectedly, we also observed non-corresponding relationships, namely negative effects of teachers' mastery goals on performance goal structures and of their performance approach goals on mastery goal structures-indicating that a theoretical understanding that refers exclusively to direct correspondence between teacher goals and their instructional behaviors is not sufficient. Instead, these findings illustrate that different sets of instructional practices are of different relevance for teachers depending on their own goals: as described above, teachers with strong mastery goals might refrain from using performance practices as these only offer limited possibilities to improve their own professional competencies. Likewise, mastery practices might not have been considered a sensible avenue by teachers with strong student-oriented performance goals as they could think, shortsightedly, that these activities are too time consuming and do not focus directly only the types of tasks (such as specific exam questions) that are needed to be fulfilled well by the students to have high achievements. Such a negative association between teachers' personal mastery goals and performance practices, has mainly been found in previous works when relying on student assessments of instructional practices, but not when asking teachers about it themselves (see Table 1). This once again affirms a discrepancy between what teachers might think to do (or want to do), and what they actually do - with the latter likely being affected by their personal goals. Finally, having found an effect of performance goals on decreased mastery practices, but not on increased performance practices, illustrates the complex mechanisms of teachers' goal striving on instructional practices and student outcomes. Only assuming that it is a focus on mastery or performance (as certain types of competence are differentially valued by individuals) that is passed through personal goals, student-oriented goals, instructional practices, and classroom goal structures, seems to be too narrow of a take. Instead, theorizing about the effects from personal goals to classroom goal structures should take into consideration how certain behaviors help to attain one's goals and how individuals (students and teachers) interpret different sets of instructional practices. We consider this to be a particularly important task for future research in order to better understand these effects. Our proposed model of operation can thereby be considered very helpful, as a detailed disentanglement of the different aspects can show the different stages in which non-correspondent effects occur.

While we found evidence supporting the mediated paths of our proposed model, we did not find direct effects of teacher goals on classroom goal structures. This may indicate a lack of strong direct effects (side paths in Figure 1): Modeling personal achievement goals or directly communicating student-oriented goals seem to be of minor significance in the classroom context (and also explain very little of the identified non-corresponding effects). As such, these findings underpin the relevance of the proposed mediational mechanisms for explaining how teacher goals affect classroom goal structures. Based on these findings, we consider it an important next step to not only consider students' perceptions of classroom goal structures but also further outcomes. Students' perceptions of classroom goal structures are linked with students' individual goals (Bardach et al., 2020; Janke et al., in press) which in turn are associated with their achievements in school (Van Yperen et al., 2014; see Wolters, 2004). However, instructional behaviors might also directly affect students' outcomes beyond changes in their motivations. To make an even stronger case for teachers' goals being relevant for students, future research should therefore not only consider mastery practices or mastery goal structures as desirable outcomes, but specifically also consider non-self-reported student outcomes, such as their achievement in school. We believe that our proposed model can provide the necessary groundwork guiding this line of research by explaining how teachers' achievement goals matter for these outcomes (besides more direct effects in particular via student-oriented goals, instructional practices, and classroom goal structures).

\section{Limitations and Practical Implications}

Although the study at hand has a number of strengths, there are also limitations that need to be considered when interpreting the results. First, due the cross-sectional design potential reverse or reciprocal effects cannot be ruled out. Future research using lon- 
gitudinal designs is required to yield a better understanding about the causality of the identified effects. Second, our study was restricted to mathematics classes, which could limit its generalizability to other subjects. For instance, it might be the case that the relatively low association between personal and studentoriented mastery goals might be in part due to the problem that providing students with novel learning opportunities in mathematics might provide less personal learning opportunities for the teacher (as this would be tied to a rather rigid curriculum) than in other subjects (like language instruction, for instance, where a new novel could be read that the teacher is not familiar with). Third, some of the intra-class-correlations of the perceived classroom goal structures were untypically low, meaning that we could not observe strong differences between different classrooms. This might be due to specific characteristics of the present sample (restricted to general-education secondary schools) or a relative insensitivity of the used measurements for classroom differences. While this constellation could have led to an underestimation of the effects on classroom goal structures and it may well be the case that the true effects are even stronger than those reported in the present work, this issue should be critically considered when interpreting the results. Finally, it should be mentioned that we only investigated mastery approach, performance approach, and performance avoidance goals. However, other types of goals such as mastery avoidance goals have also been suggested. It is also worth noting that we assessed performance goals based on a combination of appearance and normative aspects (Senko et al., 2011). Future studies might investigate both aspects separately; as it has been documented that the separating of these aspects may be important to better understand the effects of performance goals, especially in instructional contexts (Daumiller et al., 2019, 2020, 2021). Furthermore, types of goal that do not lie at the heart of competence, namely work avoidance and relational goals, have also been proposed (Butler, 2007, 2012). While first studies point to their explanatory power, it is an open question as to how they would possibly relate to student-oriented goals or to classroom goal structures. Since the latter consists of a mastery and performance structure, it makes sense to consider mastery and performance based goals on the personal level of the teacher as we did in the present work. However, future research might benefit from additionally investigating the effects from these further goals, which could have important oblique effects.

While being limited in that our findings did not consider further student outcomes (such as their actual achievement in school), our findings allow practical implications based on fostering adaptive classroom goal structures (that in turn should facilitate adaptive motivations and learning of the students; Wolters, 2004). To this end, our results point to the importance of teachers' personal and student-oriented goals. In interventions focused on fostering adaptive goals of teachers and reducing maladaptive motivations, the corresponding mastery goals should be sought to be enhanced while reducing strong performance-based goals. In doing so, our findings illustrate that it is important to address both personal as well as student-oriented goals. Beyond that, our findings might even indicate that for interventions directed at supporting instructional practices and classroom goal structures through teachers' motivations, addressing the goals that teachers hold for their students might a be particularly worthwhile approach. The goals that teachers hold for themselves might be very relevant for how they experience teaching at school (e.g., development of stress levels) or their own learning behaviors, however, with regard to instructional practices, there might be a discrepancy between self-directed goals and what teachers actually do in class - which in turn, could be more meaningfully understood and resolved through teachers' student-oriented goals.

\section{Conclusions}

Confirming our theoretical assumptions, our results indicate that teachers' personal achievement goals are related to perceived classroom goal structures via teachers' student-oriented goals and, subsequently, their sets of instructional practices. This speaks to the importance of including goals that teachers hold for their students to better understand effects of teacher motivation on instruction and student learning. Our results also advance future research in this field by demonstrating the merits of operationalizing teachers' instructional practices according to the TARGET model and measuring them by means of student assessments.

\section{References}

Ames, C. (1992). Achievement goals and the classroom motivational climate. In J. L. Meece \& D. H. Schunk (Eds.), Student perceptions in the classroom (pp. 327-348). Erlbaum.

Austin, J. T., \& Vancouver, J. B. (1996). Goal constructs in psychology: Structure, process, and content. Psychological Bulletin, 120, 338-375. https://doi.org/10.1037/00332909.120.3.338

Bardach, L., Oczlon, S., Pietschnig, J., \& Lüftenegger, M. (2020). Has achievement goal theory been right? A meta- 
analysis of the relation between goal structures and personal achievement goals. Journal of Educational Psychology, 112, 1197-1220. https://doi.org/10.1037/edu0000419

Baumert, J., Blum, W., Brunner, M., Dubberke, T., Jordan, A., Klusmann, U., ... Tsai, Y. M. (2008). Professionswissen von Lehrkräften, kognitiv aktivierender Mathematikunterricht und die Entwicklung von mathematischer Kompetenz (COACTIV): Dokumentation der Erhebungsinstrumente [Professional knowledge of teachers, cognitive activating mathematic classes and the developement of mathematical competences (COACTIV): Documentation of the measuring instruments]. Max-Planck-Institut für Bildungsforschung.

Black, A. E., \& Deci, E. L. (2000). The effects of instructors' autonomy support and students' autonomous motivation on learning organic chemistry. Science Education, 84, 740-756. https://doi.org/10/brq8jq

Buck, R., Lee, M. \& Midgley, C. (1992, April). Teachers' goals, beliefs, and perceptions of school culture as predictors of instructional practice. Paper presented at the Annual Meeting of the American Educational Research Association, San Francisco, CA.

Butler, R. (2007). Teachers' achievement goal orientation and association with teachers' help-seeking: Examination of a novel approach to teacher motivation. Journal of Educational Psychology, 99, 241-252. https://doi.org/10.1037/0022-0663.99.2.241

Butler, R. (2012). Striving to connect: Extending an achievement goal approach to teacher motivation to include relational goals for teaching. Journal of Educational Psychology, 104, 726-742. https://doi.org/10.1037/a0028613

Butler, R. (2014). What teachers want to achieve and why it matters. In P. W. Richardson, S. A. Karabenick \& H. M. G. Watt (Eds.), Teacher motivation: Theory and practice (pp. 20-35). Routledge.

Butler, R., \& Shibaz, L. (2008). Achievement goals for teaching as predictors of students' perceptions of instructional practices and students' help seeking and cheating. Learning and Instruction, 18, 453-467. https://doi.org/10.1016/j.learninstruc.2008.06.004

Cho, Y., \& Shim, S. S. (2013). Predicting teachers' achievement goals for teaching: The role of perceived school goal structure and teachers' sense of efficacy. Teaching and Teacher Education, 32, 12-21. https://doi.org/10.1016/j.tate.2012.12.003

Church, M. A., Elliot, A. J., \& Gable, S. L. (2001). Perceptions of classroom environment, achievement goals, and achievement outcomes. Journal of Educational Psychology, 93, 43-54. https://doi.org/10.1037/00220663.93.1.43

Daniels, L. M. (2015). From pre-service to practicing teacher: considering the stability of personal and classroom mastery and performance goals. Educational Psychology, 35 , 984-1005. https://doi.org/10.1080/01443410.2013.870329
Daniels, L. M., Frenzel, A. C., Stupnisky, R. H., Stewart, T. L., \& Perry, R. P. (2013). Personal goals as predictors of intended classroom goals. British Journal of Educational Psychology, 83, 396-413. https://doi.org/10.1111/j.2044-8279.2012.02069.x

Daumiller, M., Grassinger, R., Dickhäuser, O. \& Dresel, M. (2016). Structure and relationships of university instructors' achievement goals. Frontiers in Psychology, 7, 114. https://doi.org/10.3389/fpsyg.2016.00375

Daumiller, M., Dickhäuser, O. \& Dresel, M. (2019). University instructors' achievement goals for teaching. Journal of Educational Psychology, 111, 131-148. https://doi.org/10.1037/edu0000271

Daumiller, M., Janke, S., Hein, J., Rinas, R., Dickhäuser, O., \& Dresel, M. (2021). Do teachers' achievement goals and self-efficacy beliefs matter for students' learning experiences? Evidence from two studies on perceived teaching quality and emotional experiences. Learning and Instruction. Advanced online publication. https://doi.org/10.1016/j.learninstruc.2021.101458.

Dresel, M., Fasching, M. S., Steuer, G., Nitsche, S., \& Dickhäuser, O. (2013). Relations between teachers' goal orientations, their instructional practices and student motivation. Psychology, 7, 572-584. https://doi.org/10.4236/psych.2013.47083

Dresel, M., Martschinke, S., \& Kopp, B. (2009, April). Elementary school teachers' feedback practices, perceived classroom goal structures, and students' personal achievement goals. Paper presented at the 90th Annual Meeting of the American Educational Research Association (AERA) in San Diego.

Elliot, A. J. \& Hulleman, C. S. (2017). Achievement Goals. In A. J. Elliot, C. S. Dweck \& D. S. Yeager (Eds.), Handbook of competence and motivation (2nd ed., 43-60). Guilford.

Elliott, E. S., \& Dweck, C. S. (1988). Goals: An approach to motivation and achievement. Journal of Personality and Social Psychology, 54, 5-12. https://doi.org/10.1037/0022-3514.54.1.5

Gorozidis, G., \& Papaioannou, A. G. (2014). Teachers' motivation to participate in training and to implement innovations. Teaching and Teacher Education, 39, 1-11. https://doi.org/10.1016/j.tate.2013.12.001

Han, J., Yin, H., \& Wang, W. (2015). Exploring the relationship between goal orientations for teaching of tertiary teachers and their teaching approaches in China. Asia Pacific Education Review, 16, 537-547. https://doi.org/10.1007/s12564-015-9392-7

Janke, S., Bardach, L., Oczlon, S., \& Lüftenegger, M. (2019). Enhancing feasibility when measuring teachers' motivation: A brief scale for teachers' achievement goal orientations. Teaching and Teacher Education, 83, 1-11. https://doi.org/10.1016/j.tate.2019.04.003

Janke, S., Daumiller, M., Praetorius, A., Dresel, M., \& Dickhäuser, O. (in press). What reduces the adverse development of motivation at the beginning of secondary educa- 
tion: The relationship between student-perceived teaching practices and changes in students' achievement goals. Zeitschrift für Erziehungswissenschaft. https://doi.org/10.1007/978-3-658-31064-6_7.

Kalyar, M. N., Ahmad, B., \& Kalyar, H. (2018). Does teacher motivation lead to student motivation? The mediating role of teaching behavior. Voprosy Obrazovaniya, 3, 91-119. https://doi.org/10.17323/18149545-2018-3-91-119

Kaplan, A., \& Maehr, M. L. (2007). The contributions and prospects of goal orientation theory. Educational Psychology Review, 19, 141-184. https://doi.org/10.1007/s10648-006-9012-5

Kunter, M., \& Baumert, J. (2006). Who is the expert? Construct and criteria validity of student and teacher ratings of instruction. Learning Environments Research, 9, 231251. https://doi.org/10.1007/s10984-006-9015-7

Lüftenegger, M., Van De Schoot, R., Schober, B., Finsterwald, M., \& Spiel, C. (2014). Promotion of students' mastery goal orientations: Does TARGET work? Educational Psychology, 34, 451-469. https://doi.org/10.1080/01443410.2013.814189

Marsh, H. W. (1982). SEEQ: A reliable, valid, and useful instrument for collecting students' evaluations of university teaching. British Journal of Educational Psychology, 52, 77-95. https://doi.org/10.1111/j.20448279.1982.tb02505.x

Mascret, N., Elliot, A. J., \& Cury, F. (2017). The 3x2 Achievement Goal Questionnaire for Teachers. Educational Psychology, 37, 346-361. https://doi.org/10.1080/01443410.2015.1096324

Meece, J. L., Anderman, E. M., \& Anderman, L. H. (2006). Classroom goal structure, student motivation, and academic achievement. Annual Review of Psychology, 57, 487-503. https://doi.org/10.1146/annurev.psych.56.091103.070258

Midgley, C., Kaplan, A., \& Middleton, M. (2001). Performance-approach goals: Good for what, for whom, under what circumstances, and at what cost? Journal of Educational Psychology, 93, 77-86. https://doi.org/10.1037/0022-0663.93.1.77

Midgley, C., Maehr, M. L., Hruda, L. Z., Anderman, E. M., Anderman, L. H., Freeman, K. E., ... Urdan, T. (2000). Manual for the Patterns of Adaptive Learning Scales (PALS). University of Michigan.

Muthén, B. O., \& Asparouhov, T. (2009). Beyond multilevel regression modeling. J. J. Hox \& J. K. Roberts (Eds.), The handbook of advanced multilevel analysis (pp. 1540). Routledge.

Muthén, L. K., \& Muthén, B. O. (2018). Mplus [Computer Software, Version 8.1]. Muthén \& Muthén.

Nitsche, S., Dickhäuser, O., Fasching, M. S., \& Dresel, M. (2011). Rethinking teachers' goal orientations. Learning and Instruction, 21, 574-586. https://doi.org/10.1016/j.learninstruc.2010.12.001
Nitsche, S., Dickhäuser, O., Fasching, M. S., \& Dresel, M. (2013a). Teachers' professional goal orientations: Importance for further training and sick leave. Learning and Individual Differences, 23, 272-278. https://doi.org/10.1016/j.lindif.2012.07.017

Nitsche, S., Dickhäuser, O., Fasching, M. S., \& Dresel, M. (2013b). Zielorientierungen von Lehrkräften als Prädiktoren lernrelevanten Verhaltens [Teachers goal orientations as predictors of vocational learning behavior]. German Journal of Educational Psychology, 27, 95103. https://doi.org/10.1024/1010-0652/a000092

Papaioannou, A., \& Christodoulidis, T. (2007). A measure of teachers' achievement goals. Educational Psychology, 27(3), 349-361. https://doi.org/10.1080/01443410601104148

Patrick, H., Andermann, L. H., Ryan, A. M., Edelin, K. C., \& Midgley, C. (2001). Teachers' communication of goal orientations in four fifth-grade classrooms. The Elementary School Journal, 102, 35-58. https://doi.org/10.1086/499692

Peugh, J. L., \& Enders, C. K. (2004). Missing data in educational research. Review of Educational Research, 74, 525-556. https://doi.org/10.3102/00346543074004525

Ramm, G., Prenzel, M., Baumert, J., Blum, W., Lehmann, R., Leutner, D., ... Schiefele, U. (2006). PISA 2003 Dokumentation der Erhebungsinstrumente [PISA 2003 Documentation of the measuring instruments]. Waxmann.

Rattan, A., Good, C., \& Dweck, C. S. (2012). "It's ok-Not everyone can be good at math": Instructors with an entity theory comfort (and demotivate) students. Journal of Experimental Social Psychology, 48, 731-737. https://doi.org/10.1016/j.jesp.2011.12.012

Retelsdorf, J., Butler, R., Streblow, L., \& Schiefele, U. (2010). Teachers' goal orientations for teaching: Associations with instructional practices, interest in teaching, and burnout. Learning and Instruction, 20, 34-43. https://doi.org/10.1016/j.learninstruc.2009.01.001

Retelsdorf, J. \& Günther, C. (2011). Achievement goals for teaching and teachers' reference norms: Relations with instructional practices. Teaching and Teacher Education, 27 ,

1111-1119. https://doi.org/10.1016/j.tate.2011.05.007

Runhaar, P., Sanders, K., \& Yang, H. (2010). Stimulating teachers' reflection and feedback asking: An interplay of self-efficacy, learning goal orientation, and tranformational leadership. Teaching and Teacher Education, 26, 1154-1161. https://doi.org/10.1016/j.tate.2010.02.011

Schiefele, U., \& Schaffner, E. (2015). Teacher interests, mastery goals, and self-efficacy as predictors of instructional practices and student motivation. Contemporary Educational Psychology, 42, 159-171. https://doi.org/1 10.1016/j.cedpsych.2015.06.005

Senko, C., Hulleman, C., \& Harackiewicz, J. (2011). Achievement goal theory at the crossroads: Old contro- 
versies, current challenges, and new directions. Educational Psychologist, 46, 26-47. http://dx.doi.org/10.1080/00461520.2011.538646

Schöne, C., Dickhäuser, O., Spinath, B. \& Stiensmeier-Pelster, J. (2004). Zielorientierung und Bezugsnormorientierung [Goal orientation and reference-norm orientation]. Zeitschrift für Pädagogische Psychologie, 18, 93-99. https://doi.org/10.1024/1010-0652.18.2.93

Shim, S. S., Cho, Y., \& Cassady, J. (2013). Goal structures: The role of teachers' achievement goals and theories of intelligence. The Journal of Experimental Education, 81, 84-104. https://doi.org/10.1080/00220973.2011.635168

Steuer, G., Rosentritt-Brunn, G. \& Dresel, M. (2013). Dealing with errors in mathematics classrooms. Contemporary Educational Psychology, 38, 196-210. https://doi.org/10.1016/j.cedpsych.2013.03.002

Skaalvik, E. M., \& Skaalvik, S. (2017). Motivated for teaching? Associations with school goal structure, teacher selfefficacy, job satisfaction and emotional exhaustion. Teaching and Teacher Education, 67, 152-160. https://doi.org/10.1016/j.tate.2017.06.006

Turner, J. C., Midgley, C., Meyer, D. K., Gheen, M., Anderman, E. A., Kang, Y., \& Patrick, H. (2002). The classroom environment and students' reports of avoidance strategies in mathematics. Journal of Educational Psychology, 94, 88-106. https://doi.org/10.1037/00220663.94.1.88

Urdan, T., \& Kaplan, A. (2020). The origins, evolution, and future directions of achievement goal theory. Contemporary Educational Psychology, 61, 101862. https://doi.org/10.1016/j.cedpsych.2020.101862

Van Yperen, N. W., Blaga, M., \& Postmes, T. (2014). A meta-analysis of self-reported achievement goals and nonself-report performance across three achievement domains (work, sports, and education). PloS one, 9(4), e93594. https://doi.org/10.1371/journal.pone.0093594

Wang, H., Hall, N. C., Goetz, T., \& Frenzel, A. C. (2017). Teachers' goal orientations: Effects on classroom goal structures and emotions. British Journal of Educational Psychology, 87, 90-107. https://doi.org/10.1111/bjep.12137

Wild, E. (1999). Elterliche Erziehung und schulische Lernmotivation [Parental education and academic learning motivation]. Unpublished professorial dissertation. University of Mannheim, Germany.

Wolters, C. A. (2004). Advancing achievement goal theory: Using goal structures and goal orientations to predict students' motivation, cognition, and achievement. Journal of Educational Psychology, 96(2), 236-250. https://doi.org/10.1037/0022-0663.96.2.236

Yin, H., Han, J., \& Lu, G. (2017). Chinese tertiary teachers' goal orientations for teaching and teaching approaches: The mediation of teacher engagement. Teaching in Higher Education, 22, 766-784. https://doi.org/10.1080/13562517.2017.1301905

Note. This is a pre-copyedited, author-produced PDF of an article submitted for publication. This paper is not the copy of record and may not exactly replicate the final, authoritative version of the article. The final article will be available, upon publication, via its DOI. 


\section{Footnotes}

${ }^{1}$ Butler $(2007,2012)$ also considered work avoidance and relational goals of teachers. Since these goals are not concerned with competence to the same degree as mastery and performance goals, we do not focus on them in the present work (see Elliot \& Hulleman, 2017; and Daumiller et al., 2019, for a comprehensive overview model of theoretically distinguishable types of goals for teaching)

${ }^{2}$ Results of an explorative factor analysis with oblique rotation indicated that a separation into approach and avoidance factors is not obvious.

${ }^{3}$ To investigate the robustness of our results and to determine the impact of including "individualization of learning time" as an aspect of "performance practices", we additionally computed our main analyses without this aspect. The estimated model provided a slightly worse fit to the data, and all parameter estimates and their statistical significance did not change substantially. This means that the inclusion of this aspect as performance practices does not have a substantial effect on our findings that would need to be borne in mind when interpreting our results.

${ }^{4}$ While this model directly reflects our theoretical assumptions of personal goals being related to instructional practices via student-oriented goals, it needs to be borne in mind that the cross-sectional design of our study does not allow for causal conclusions. To provide further indications for the order of the constructs in this model, we additionally estimated a series of alternative models (e.g., with the order of student-oriented goals and personal goals interchanged). Specifically, we considered all five alternative orders between personal goals, student-oriented goals, and instructional practices that are possible — all of these alternative models provide a worse fit to the data than the presented model (reflected in higher AIC, BIC, and SBIC values). 


\section{Supplementary Material}

Table S1

Items of the Questionnaire to Assess Teachers' Student-oriented Goals

Item text (item stem: "In my math class [In meinem Mathematikunterricht] ...")

Student-oriented mastery classroom goals

1. it is very important to me that my students learn something new [ist es mir sehr wichtig, dass meine Schüler Neues lernen].

2. my main goal is that my students learn a lot of new things [geht es mir vor allem darum, dass meine Schüler viele neue Dinge lernen].

3. my main goal is that my students learn more and improve themselves [geht es mir vor allem darum, dass meine Schüler dazulernen und sich verbessern].

4. my main goal is that every single student improves, no matter how good they are [ist es mein

Hauptziel, dass sich jeder einzelne Schüler verbessert, egal wie gut er ist].

5. it is really important to me that my students expand their knowledge [ist es mir wirklich wichtig, dass meine Schüler ihr Wissen erweitern].

6. my main goal is that my students' competence increases [geht es mir vor allem darum, dass meine

Schüler immer mehr können].

7. my most important goal is that my students really understand the subject matter [ist es mir das

Wichtigste, dass meine Schüler den Stoff wirklich verstehen].

8. my main goal is that my students understand complex content [geht es mir vor allem darum, dass meine Schüler komplizierte Inhalte verstehen.].

Student-oriented performance classroom goals

9. my main goal is that my students achieve good performance [geht es mir vor allem darum, dass

meine Schüler gute Leistungen erbringen].

10. my most important goal is that my students score well in examinations [ist es mir das Wichtigste,

dass meine Schüler bei Prüfungen gut abschneiden].

11. it is essential to me that my students are good [kommt es mir vor allem darauf an, dass meine

Schüler gut sind].

12. it is important to me that my students are better than other students [ist es mir wichtig, dass meine

Schüler besser sind als andere Schüler].

13. it is important to me that my students perform better in examinations than other students [ist es mir wichtig, dass meine Schüler bei Prüfungen besser abschneiden als andere Schüler].

14. my main goal is that my students show better achievements than other students [geht es mir darum, dass meine Schüler bessere Leistungen erbringen als andere Schüler].

15. the most important goal for me is that my students do not have bad examination results [ist es mir das Wichtigste, dass meine Schüler keine schlechten Leistungen erbringen].

16. my main goal is that my students do not perform poorly in exams [geht es mir vor allem darum, dass meine Schüler bei Prüfungen nicht schlecht abschneiden].

17. it is important to me that my students are not bad [kommt es mir darauf an, dass meine Schüler nicht schlecht sind].

18. my main goal is that my students do not perform worse than other students [geht es mir vor allem darum, dass meine Schüler bei Prüfungen nicht schlechter abschneiden als andere Schüler].

19. it is important to me that my students are not worse than other students [kommt es mir darauf an, dass meine Schüler nicht schlechter sind als andere Schüler].

20. it is important to me that my students' achievements are not worse than those of other students [ist es mir wichtig, dass meine Schüler keine Leistungen erbringen, die schlechter sind als die von anderen Schülern].

Note. $n=84$ teachers. Items were presented along with Likert-type scales ranging from 1 (not true at all) to 6 (completely true). German original formulations in brackets. Student-oriented mastery goals and student-oriented performance goals correlated with $r=.25(p<.05)$. 
Table S2

Zero Order Correlations $\mathrm{r}$ among Teacher Variables

\begin{tabular}{lrrrr}
\hline & 1 & 2 & 3 & 4 \\
\hline Teachers' goal orientations & & & & \\
1 Learning & -.03 & & & \\
2 Performance approach & .02 & .27 & & \\
3 Performance avoidance & & & & \\
Teachers' student-oriented goals & .25 & .05 & -.04 & \\
4 Mastery & .03 & .49 & .16 & .24 \\
5 Performance &
\end{tabular}

Note. $N=84$ teachers. All $|r| \geq .23: p<.05 .|r| \geq .26: p<.01 .|r| \geq .33: p<.001$. 
Table S3

Zero Order Correlations $\mathrm{r}$ and Intra-Class-Correlations ICCI and ICC2 among Student Variables

\begin{tabular}{|c|c|c|c|c|c|c|c|c|c|c|c|c|c|c|c|c|c|c|c|c|c|}
\hline & ICC1 & ICC2 & 1 & 2 & 3 & 4 & 5 & 6 & 7 & 8 & 9 & 10 & 11 & 12 & 13 & 14 & 15 & 16 & 17 & 18 & 19 \\
\hline \multicolumn{22}{|c|}{ Students' reports of teachers' instructional practices } \\
\hline 1 Interestingness of instruction & $.18^{*}$ & .79 & & & & & & & & & & & & & & & & & & & \\
\hline 2 Cognitive stimulation & $.11^{*}$ & .68 & .52 & & & & & & & & & & & & & & & & & & \\
\hline 3 Structuring of content & $.10^{*}$ & .66 & .61 & .34 & & & & & & & & & & & & & & & & & \\
\hline 4 Clarity of explanations & $.18^{*}$ & .79 & .86 & .34 & .40 & & & & & & & & & & & & & & & & \\
\hline 5 Autonomy support & $.16^{*}$ & .77 & .51 & .38 & .39 & .51 & & & & & & & & & & & & & & & \\
\hline 6 Constructive error climate & $.18^{*}$ & .79 & .53 & .27 & .33 & .59 & .45 & & & & & & & & & & & & & & \\
\hline 7 Support for competence & $.12^{*}$ & .82 & .56 & .33 & .33 & .60 & .46 & .73 & & & & & & & & & & & & & \\
\hline 8 Support for relatedness & $.21^{*}$ & .70 & .58 & .29 & .41 & .57 & .49 & .54 & .57 & & & & & & & & & & & & \\
\hline 9 Cooperation & $.15^{*}$ & .75 & .54 & .25 & .35 & .42 & .42 & .37 & .38 & .57 & & & & & & & & & & & \\
\hline 10 Competition & $.11^{*}$ & .68 & .18 & .10 & .15 & .02 & .09 & -.13 & .08 & .15 & .32 & & & & & & & & & & \\
\hline 11 Homogeneous grouping & $.12^{*}$ & .70 & -.05 & -.05 & -.04 & -.16 & -.07 & -.30 & -.09 & -.06 & .06 & .48 & & & & & & & & & \\
\hline 12 Heterogeneous grouping & $.06^{*}$ & .52 & .20 & .17 & .20 & .15 & .22 & .21 & .21 & .21 & .31 & .17 & -.10 & & & & & & & & \\
\hline 13 Intrapersonal grading standards & $.04^{*}$ & .42 & .25 & .22 & .17 & .27 & .25 & .26 & .41 & .28 & .18 & -.09 & -.13 & .15 & & & & & & & \\
\hline 14 Normative grading standards & .02 & .26 & -.05 & .01 & -.01 & -.09 & -.04 & -.24 & .01 & -.02 & .01 & .24 & .19 & -.08 & .08 & & & & & & \\
\hline 15 Publication of marks & $.20^{*}$ & .81 & -.06 & .02 & -.05 & -.13 & -.04 & -.25 & -.10 & -.04 & .01 & .27 & .24 & -.01 & -.10 & .18 & & & & & \\
\hline 16 Public negative feedback & $.08 *$ & .60 & -.05 & .01 & .01 & -.17 & -.02 & -.32 & -.07 & -.08 & .02 & .34 & .38 & -.04 & -.03 & .22 & .34 & & & & \\
\hline 17 Individualization & $.08^{*}$ & .60 & .15 & .18 & .18 & .04 & .14 & -.04 & .10 & .13 & .30 & .46 & .29 & .10 & .06 & .15 & .24 & .31 & & & \\
\hline \multicolumn{22}{|c|}{ Students' reports of classroom goal structures } \\
\hline 18 Mastery & $.07^{*}$ & .56 & .43 & .32 & .33 & .43 & .37 & .45 & .45 & .41 & .33 & .02 & -.19 & .26 & .37 & .03 & -.09 & -.08 & .10 & & \\
\hline 19 Performance approach & $.03 *$ & .35 & .17 & .14 & .16 & .11 & .10 & .04 & .19 & .18 & .16 & .19 & .08 & .10 & .18 & .24 & .09 & .15 & .16 & .50 & \\
\hline 20 Performance avoidance & $.03^{+}$ & .35 & .03 & -.01 & .03 & -.04 & -.06 & -.26 & .01 & .01 & .09 & .38 & .31 & -.10 & .01 & .42 & .23 & .32 & .30 & .10 & .46 \\
\hline
\end{tabular}

Note. $N=1,447$ students from 84 classrooms/teachers. All $|r| \geq .04: p<.05 .|r| \geq .06: p<.01 .|r| \geq .08: p<.001 .{ }^{*} p<.05,{ }^{+} p<.10$. 